\title{
The Impact Of Environmental Degradation On Human Health And Its Relevance To The Right To Health Under International Law
}

\author{
Dr Maryam Ishaku Gwangndi, Associate Prof. \\ Dr Yahaya Abubakar Muhammad, Associate Prof. \\ Dr Sule Musa Tagi, Senior Lecturer
}

Department of Public Law University of Maiduguri Borno State Nigeria

doi: 10.19044/esj.2016.v12n10p485 URL:http://dx.doi.org/10.19044/esj.2016.v12n10p485

\begin{abstract}
When natural habitats are destroyed or natural resources are depleted the environment is degraded. Environmental degradation results from factors such as urbanisation, population growth, intensification of agriculture, rising energy use and transportation, climate change, pollutions arising from many sources such as technological activities. It is explored that as a result of the dynamic interplay of socio-economic factors and technological activities amongst many other factors, these have devastating consequences on human health. Thus environmental degradation consequences affect the health and the right to health of the people. Using the doctrinal method of research, we examine the confluence of environmental degradation and health from a rights perspective. An unhealthy environment possess health hazards consequently a violation of the right to health. The article recommends that states' obligation under international law to protect the right to health should be enforceable. Human beings are entitled to right to health even as the environment needs to be protected from activities which cause environmental degradation.
\end{abstract}

Keywords: Environment, Environmental Degradation, Right to Health, Right to a Healthy Environment

\section{Introduction}

The environment plays a central role in the life of human beings. The environment directly affects the health status and well-being of human population whether in the urban cities or in hinterlands. It has been established that "The potential adverse effects of climate change have been characterised as changes in the physical environment or biota which have significant deleterious effects on the composition, resilience or productivity 
of natural or managed ecosystems or on the operation of socio- economic systems or on human health and welfare,'1. Furthermore, it has also been established that a contaminated environment due to human activities could cause malnutrition and diseases, morbidity and shortening of life span ${ }^{2}$.

The enjoyment of human rights and the relationship it has with the environment in which people live was for the first time addressed in 1972 at the UN Conference on the Human Environment. The Declaration of the Conference otherwise known as the (Stockholm Declaration) makes recognition of the fact that 'man's environment \{is\} essential to his well being and to the enjoyment of basic human rights', such as the right to life. It goes without saying that ' 'The harm caused to individuals and communities by degraded environments- from unsafe drinking water to disappearing wild life- is increasingly seen by many people as a question of rights' being violated......Protection of the environment can no longer be seen as simply a policy choice, 3 .

Thus this article examines the factors that cause environmental degradation and the attendant consequences on human health. It highlights steps that need to be taken by governments as well as individuals and private companies with a view to protecting the environment from degradation in order to protect the health and the right to health of the people.

\section{Definitions and meanings of environmental terms}

\section{(a) Environment}

The Oxford Advanced Learner's Dictionary International Student's Edition defines the environment as the natural world in which people, animals and plants live". Again it has been defined as "conditions, circumstances etc affecting people's lives. It is the complex of physical, chemical and biotic factors that act upon an organism or an ecological community and ultimately determines its form and survival", ${ }^{5}$ In any way

\footnotetext{
${ }^{1}$ Mohammed A, Alamin, ‘An Assessment of Nigeria’s preparedness to Environmental Disasters From Its Commitment to International Environmental Treaties'; European Scientific Journal Volume 9 No. 32 November 2013 edition p. 250.

${ }^{2}$ Sajini Faith Iwejingi, 'Population Growth, Environmental Degradation and Human Health in Nigeria', Pakistan Journal of Social Sciences, Volume 8 No. 4 (2011) p. 187.

${ }^{3}$ Kravchencko and Bonine, Human Rights and the Environment: Cash, Law and Policy, (Carolina Academic Press 2008) p. 3.

${ }^{4}$ N.A The Oxford Advanced Learner's Dictionary International Student's Edition, (Oxford: Oxford University Press 2015) p. 491.

${ }^{5}$ Angela Kesiena Etuonovbe, 'The Devastating Effects of Environmental Degradation- A Case Study of the Niger delta Region of Nigeria', TSID-Environment and Land Use Planning FIG Working Week 2009 Surveyors Key Role in Accelerated Development Eitat, Israell, 3-8 May, 2008.
} 
when the environment becomes less valuable or damaged, environmental degradation is said to occur ${ }^{6}$.

\section{(b) Environmental Degradation}

"Environmental degradation is the deterioration of the environment through depletion of resources such as air, water, soil; the destruction of ecosystems and the extinction of wild life. It is defined as any change or disturbance to the environment perceived to be deleterious or undesirable" ${ }^{\text {, }}$.

In accordance with the I=PAT equation, "environmental impact

(I) or degradation is caused by the combination of an already very large and increasing human population $(\mathrm{P})$, continually increasing economic growth or per capita affluence (A), and the application of resource depleting and polluting technology $(\mathrm{T})^{8}$.

The United Nations through the High-Level Panel on Threats, Challenges and Change officially stated and also cautioned that environmental degradation is one of the ten threats to human existence. Thus The United Nations International Strategy for Disaster Reduction defines environmental degradation as "the reduction of the capacity of the environment to meet social and ecological objectives, and needs", .

Degradation of the environment, by which we mean the deterioration in environmental quality from ambivalent concentrations of pollutants and other activities and processes, such as improper land use and natural disasters ${ }^{10}$ can cause violations of human rights. For example as far back as 2009, the Office of the UN High Commissioner for Human Rights investigated the varied effects of climate change on the enjoyment of human rights. It made a report in 2009 to the Human Rights Council, on the impact of climate change on several human rights, including the rights to life, adequate food, water, adequate housing, health and self-determination ${ }^{11}$.

"The report notes that the effects of climate change, including heatwaves, floods, and other natural phenomena, will pose direct and indirect

\footnotetext{
${ }^{6}$ Ibid.

${ }^{7}$ Johnson, D. L. Et al, 'Meanings of Environmental Terms', Volume 26, (1997) Journal of Environmental Quality pp. 581-589.

${ }^{8}$ Chertow, Marian. R, 'The IPAT equation and its variants', Volume 4 no. 4 (2001) Journal of Induetrial Ecology, pp. 13-28; Huesemann, M.H. and Joyce A, Huesmann, 'Technofix: Why Technology Won't Save US or the Environment', Chapter 6, Sustainability or Collapse? (New Society Publishers 2011) Available at (http://www.newtechnology and society, org),

9 “'ISDR :Technology'. The International Strategy for Disaster Reduction, 2004-03-31 Accessed 2010-06-09.

10 OECD Glossary of Statistical Terms, available at<http://ststs.oecd.org/glossary/detail.asp?ID=821>

${ }^{11}$ Report of the OHCHR on the relationship between climate change and human rights, A/HRC/10/61 (15 January 2009).
} 
threats to the right to life and the closely related rights to food, water, health, and housing $^{12}$.

Therefore, it could safely be inferred that climate change poses a very serious challenge to the right to life and health.

The Committee on Economic, Social and Cultural Rights, also took note of the threat caused by environmental degradation on the enjoyment of human rights. In its General Comment 14, " the Committee observed that the steps that should be taken to realise the right to health, and in particular the improvement of all aspects of environmental and industrial hygiene include preventive measures in respect of occupational accidents and diseases; the requirement to ensure an adequate supply of safe and potable water and basic sanitation; the prevention and reduction of the population's exposure to harmful substances such as radiation and harmful chemicals or other detrimental environmental conditions that directly or indirectly impact upon human health",13.

It has been established that there is a negative link between environmental degradation and the enjoyment of human rights ${ }^{14}$. It is widely acknowledged that the effect of dumping of toxic waste has link with the enjoyment of human rights. In 1995, a Special Rapporteur was set up by the Commission on Human Rights to investigate whether there was such a link. As a result of this step taken, in 1996, "the Rapporteur reported that environmental degradation following the dumping of toxic waste would impact on the enjoyment of human rights to self-determination, life, health, food, safe and healthy working conditions, housing, information, participation, freedom of association, as well as cultural rights, ${ }^{, 15}$.

Thereafter there were several emphasis on the said adverse effects as evidenced by the Commission on Human Rights and Human Rights Council Resolutions $^{16}$.

\footnotetext{
${ }^{12}$ Ibid.

${ }^{13}$ See CESR, General Comment 15, HR1/GEN/1/Rev.9 (Vol. 1) 97. See also Fitzmaurice, 'The Human Right to Water' Volume 18, (2007) Fordham Environmental Law Report, p. 537.

${ }^{14}$ Malgosia FitzMaurice, 'Environmental Degradation', in Daniel Moeckli, Sangeeta Shah, and Sadesh Sivakumaran (eds) and David Harris (Consultant editor), International Human Rights Law (Oxford: Oxford University Press 2010) p. 624.

${ }^{15}$ Preliminary report of the Special Rapporteur on the adverse effects of the illicit movement of toxic and dangerous products and wastes on the enjoyment of human rights, E/CN. 4/1996/17 (22 February 1996).

${ }^{16}$ See for example HR Council Res9/1 (September 2008).
} 


\section{Legal Regulation of the Human Environment and its Protection Globally}

(a) Principle 1 of the Stockholm Declaration on the Human Environment 1972 provides the basis for the protection of the environment in international relation. It places the issue of protection of biosphere on the official agenda of policy and law of the member states. Thus Environmental instruments linking the environment and human rights began to be established as early as 1972. This is provided in the Stockholm Declaration on Human Environment, which states that "Man has the fundamental right to freedom, equality and adequate conditions of life, in an environment of quality that permits a life of dignity and wellbeing', It is therefore imperative that man should protect the environment in a sustainable manner for future generations. In line with this Principle 6 provides for the halting of the discharge of toxic substances that can cause serious or irreversible damage to ecosystems. Principle 15 makes provision for appropriate planning with regard to human settlement and urbanisation in order to avoid adverse effects on the environment. Principle 18 has to do with "Precautionary Principle", with a view to avoiding environmental risks.

Many of the Principles arising from the Stockholm Declaration on Human Environment contain adequate provisions on risk avoidance, risk reduction thus integrating the environment as a part of the Disaster Risk Reduction and Sustainable Development.

(a) The Vienna Convention for the Protection of the Ozone Layer $^{17}$ This Convention was entered with the purpose to protect human health and the environment against adverse effects resulting from human activities which modify or likely to modify the Ozone layer and urges the Parties to the Convention to take appropriate measures in accordance with the provisions of the Convention and its Protocols applicable to that party. In addition to the Convention there is also the Montreal Protocol on Substances that deplete the Ozone layer which was adopted in 1987. It is a Protocol to the Vienna Convention. By Article 6 of the Protocol, the control measures are revised every four years starting from 1996.

(b) The Basel Convention on the Control of Trans-boundary Movements of Hazardous Wastes and their disposal-This was adopted on 22 March 1989 by the Conference of Plenipotentiaries in Basel, Switzerland. This Convention became necessary in view of the discovery of toxic wastes in Africa in the 1980s, and other parts of developing world imported from

${ }^{17}$ Adopted, 1985 and it entered into force, 1988. 
abroad. The overall objective of this Convention is to protect human health and the environment against adverse effects of hazardous wastes ${ }^{18}$.

(c) The Biodiversity Convention- The purpose of this Convention is to provide a number of general obligations for member states. In particular a commitment to develop national strategies, plans and programmes for the conservation and sustainable use of biological diversity. Among so many obligations is the promotion of the protection of ecosystems, natural habitats, the promotion of environmentally sound and sustainable development rehabilitation and restoration of degraded ecosystems, protection of workers etc.

(d) The United Nations' Frame work Convention on Climate Change is concerned with greenhouse warming. This Convention was adopted in Kyoto on December 11, 1997 with different goals and commitments concerning emission of greenhouse gases. This was a follow up to the Earth Summit (also known as the United Nations Conference on Environment and Development) (UNCED) the Rio de Janeiro Earth Summit. It was a major United Nations Conference held in Rio de Janeiro from 3-14 June 1992. In 2012, the United Nations Conference on Sustainable Development was also held in Rio, and is also commonly called Rio+20 or Rio Earth Summit 2012. It was held from 13-22 June 2012.

The issues addressed included systematic scrutiny of patterns of production particularly the production of toxic compounds, such as lead in gasoline, or poisonous waste including radioactive chemicals. Others are alternative sources of energy to replace the use of fossil fuels which delegates linked to global climate change. Furthermore new reliance on public transportation systems in order to reduce vehicle emissions, congestion in cities and the health problems caused by polluted air and smoke. The growing usage and limited supply of water was also an issue discussed.

The Summit was successful and there were important achievements. The most important achievement was an agreement on the Climate Change Convention which in turn led to the Kyoto Protocol. It was agreed "not to carry out any activities on the lands of indigenous peoples that would cause environmental degradation or that would be culturally inappropriate" ${ }^{19}$.

It was at this Earth Summit that the Convention on Biological Diversity was opened for signature and this paved the way for a start towards redefinition of measures that did not inherently encourage destruction of natural eco-regions and so-called uneconomic growth. This Summit resulted

\footnotetext{
${ }^{18}$ See Koko toxic Waste deposited in Nigeria in 1988 as an example which case is later discussed in the article.

${ }^{19}$ See Articles 14 and 15 of International Labour Organisation (ILO) Convention No 169.
} 
in some documents which are: Rio Declaration on Environment and Development $^{20}$, Agenda $21^{21}$ and Forest Principles. On the whole, some important legally binding agreements (Rio Convention) were opened for signature, which include Convention on Biological Diversity ${ }^{22}$, Framework Convention on Climate Change (UNFCCC), United Nations Convention to Combat Desertification.

In order to ensure compliance to the agreements at Rio (particularly the Rio Declaration on Environment and Development and Agenda 21), delegates to the Earth Summit established the Commission on Sustainable Development (CSD). In 2013, the CSD was replaced by the High-Level Political Forum on Sustainable Development that meets every Fourth Year as part of the General Assembly meetings.

Climate change is a common concern of humankind and so as a result of building upon previous Earth Summits the Paris Agreement (Framework on Climate Change) was signed on 12-12-2015. By Article 21 of the Agreement it is stated that :

This Agreement shall enter into force on the thirtieth day after the date on which at least 55 parties to the Convention accounting in total for at least an estimate 55 percent of the total global greenhouse gas emission have deposited their instruments of ratification, acceptance, approval or accession",23.

By Article 20, "This Agreement shall be open for signature and subject to ratification, acceptance or approval by states and regional economic integration organisations that are parties to the Convention. It shall be open for signature at the United Nations Headquarters in New York from 22 April 2016 to 21 April 2017. Thereafter, this Agreement shall be open for accession from the day following the date on which it is closed for signature. Instruments of ratification, acceptance, approval or accession shall be deposited with the Depository, ${ }^{24}$.

It is no longer in doubt that there is great urgency in addressing the impact of climate change just as the climate change itself is unfolding rapidly. United Nations FCCC aptly captures this. ${ }^{25}$.

Furthermore, it "acknowledges that climate change is a common concern of humankind, parties should, when taking action to address climate

\footnotetext{
${ }^{20}$ United Nations Conference on Environment and Development. "Rio Declaration on Environment and Development”' Habitat.igc.org. Retrieved 4 ${ }^{\text {th }}$ August 2014.

${ }^{21}$ United Nations Conference on Environment and Development "Agenda 21: Eartg Summit, 1992'’. Habitat.igc.org. Retrieved $4^{\text {th }}$ August 2011.

${ }^{22}$ CBD Home. Cbd.int. Retrieved 2014-08-04.

${ }^{23}$ United Nations FCCC/CP/2015/L.9/Rev.1

${ }^{24}$ Ibid. P.31.

${ }^{25}$ United Nations op. cit, foot note 18.
} 
change, respect, promote and consider their respective obligations on human rights, the right to health, the rights to indigenous peoples, local communities, migrants, children, persons with disabilities and people in vulnerable situations and the right to development, as well as gender equality, empowerment of women and intergenerational equity, 26 .

\section{Substantive environmental rights}

Only few human rights treaties grant a direct right to a clean and healthy environment. The African Charter on Human and Peoples' Rights (ACHPR) and the San Salvador Protocol to the American Convention on Human Rights in the Area of Economic, Social and Cultural Rights (San Salvador Protocol) are the only two which grant such right. However, even in the absence of many of such rights, it should be noted that the UN has made some progress towards drafting 'soft law' documents that suggest that there might be a substantive human right to a clean and healthy environment ${ }^{27}$. Not only that, in addition the European Court of Human Rights has also found that such a right can be derived by looking into the operational bases of the existing human rights ${ }^{28}$.

\section{African Charter}

The African Carter is the first treaty to provide for a direct right to a clean and healthy environment. Article 24 in particular makes provision to peoples with a right to "a general satisfactory environment favourable to their development". It was this Article 24 that provided the platform upon which the Ogoniland case's claim was based before the African Commission on Human and Peoples' Rights ${ }^{29}$. In this case the complainants alleged that the Nigerian government had directly participated in the unsustainable oil development practices in Ogoni land. Part of the claim was that the stateowned oil company had caused environmental degradation, including widespread contamination of soil, water, and air, the destruction of homes, the burning of crops, and the killing of farm animals. As a consequence of these actions, it had led to health problems amongst the Ogoni people.

\footnotetext{
${ }^{26}$ Ibid.

${ }^{27}$ Daniel Moeckli et al, op. Cit. p.624.

${ }^{28}$ Ibid.

${ }^{29}$ 155/96, Social and Economic Rights Action Center and the Center For Economic and Social Rights v Nigeria, $15^{\text {th }}$ Activity Report of the AComm HPR (2001-2002) (Ogoniland). See Shelton, 'Decision Regarding Communication 155/96 (Social and Economic Rights Action Centre/Centre for Economic and Social Rights $\mathrm{v}$ Nigeria). Case NO. ACHPR/COMM/A044/1(2002) 96 AJIL937; Coomans, "The Ogoni Case before the African Commission on Human and Peoples’ Rights (2003) 52 ICLQ 749.
} 
Furthermore, allegations of violations of the right to health, a healthy environment, housing, and food were also made ${ }^{30}$.

"The African Commission held that the right to a satisfactory environment as set out in Article 24 requires States Parties to adopt reasonable measures to prevent pollution and ecological degradation, to promote conservation, and to pursue the concept of sustainable development and use of natural resources. Furthermore, a satisfactory environment is one which is clean and safe and promotes health", ${ }^{\text {, }}$.

Therefore in the same manner, the right to health imposes obligation on states to 'take the necessary measures to protect the health of their people ${ }^{32}$. The Commission was of the view that states must respect these rights by refraining from directly threatening the health and the environment of their citizens as well as protect the environment from pollutions and ecological degradation ${ }^{33}$.

\section{San Salvador Protocol to the American Convention on Human Rights}

Article 11 San Salvador Protocol provides for a right to a healthy environment:

1. Everyone shall have a right to live in a healthy environment and to have access to basic public services.

2. The State Parties shall promote the protection, preservation, and improvement of the environment.

It is however worthy of note that, despite these provisions as stated above, the Inter American human rights institutions have limited powers in respect of this right. All they are able to do is just to be receiving annual reports from States on their observation of this right. This is because there is no provision for individual applications to the Inter-American Commission or Court regarding alleged violations of the San Salvador Protocol ${ }^{34}$. In any case, the Commission and the Court have been able to link environmental degradation and human rights on several occasions ${ }^{35}$.

\footnotetext{
${ }^{30}$ As reported by Daniel Moeckli et al op. cit. p625.

${ }^{31}$ Ibid.

${ }^{32}$ ACHPR, Article 16.

${ }^{33}$ Daniel Moeckli et al op. cit. footnote 30.

${ }^{34}$ Ibid.

35 Case 7615, Yanomani v Brazil, 1ACommHR Res112/85 (5 March 1985); Mayagna (Sumo) Awas Tigni Community v Nicaragua, IACtHR Series CNO. 79 (31 August 2001); Case 12/053, Maya Indiigenuous Community of the Toledo Districtv Belize, IACommHR Report NO. 40/40 (12 October 2004) as quoted by Daniel Moeckli et al op. cit. p. 626.
} 


\section{Efforts made so far with regard to providing for Substantive Environmental Human Rights}

At the UN several 'soft law' instruments have been adopted which could lead to a suggestion that there is a possibility of establishment of substantive environmental human right ${ }^{36}$. An example of such instrument is the provision as contained in Principle 1 Stockholm Declaration which provides that "Man is both creature and moulder of his environment, which gives him physical sustenance and affords him the opportunity for intellectual, moral, social and spiritual growth. In the long and for continuous evolution of the human race on this planet a stage has been reached when, through the rapid acceleration of science and technology, man has acquired the power to transform his environment in countless ways and on an unprecedented scale. Both aspects of man's environment, the natural and the man-made, are essential to his well-being and to the enjoyment of basic human rights the right to life itself (sic).

It has been observed that the Stockholm Principle 1 is an incipient to environmental human rights. However, its impact is not elaborate on the world scene ${ }^{37}$.

In 1992, world leaders met at the UN Conference on the Environment and World Development. It was hoped that this Conference would produce a document which would include an explicit human right to a clean environment. However, such a perceived document was not produced. Instead, the Rio Declaration did not shift away from the position taken in Stockholm which is that: "Human beings are at the centre of concerns for sustainable development. They are entitled to a healthy and productive life in harmony with nature”.

In 1998 before the Rio Conference, a Special Rapporteur on environmental development was appointed by the Sub-Commission on Prevention of Discrimination and Protection of Minorities in 1994. The Special Rapporteur, Fatma Zohra Ksentini, in her special report identified the link between human rights and environmental degradation ${ }^{38}$.

"She stated that the environment, development, democracy and human rights are the fundamental building blocks of modern society endorsing the view that environmental rights are protected by existing human rights, she ported that there was universal acceptance of the right to a satisfactory environment at national, regional, and international levels. The Special Rapporteur recommended the adoption of the Draft Declaration of Principles on Human Rights and

\footnotetext{
${ }^{36}$ Ibid.

${ }^{37}$ Boyle, 'Human Rights or Environmental Rights? A Reassessment' Volume 18 (2007) Fordham Environmental Law Report 471, 476.

${ }^{38}$ Daniel Mocklei et al op. cit. p. 627.
} 
the Environment which had been drafted by academics and NGOs", 39 .

Based on the presumption that environmental human rights exist, the Draft Declaration builds on the Stockholm and Rio Declarations and provides that:

1. Human rights, an ecologically sound environment, sustainable development and peace are interdependent and indivisible.

2. All persons have the right to a secure, healthy and ecologically sound environment. This right and other human rights including civil, cultural, economic, political and social rights, are universal, interdependent and indivisible.

The Draft Declaration contain a wide range of both sustainable and procedural environmental rights which include rights to freedom from pollution, environmental degradation, activities that poses as threat to health, within, across or outside national boundaries, the right to safe and healthy food and water, a healthy working environment among many others ${ }^{40}$.

\section{Indirect Substantive Environmental Rights}

In the Special Rapporteur's report, on environment and development, rights to a clean and healthy environment may be drawn from other human rights: civil, and political, as well as economic, social, and cultural rights. It has been established that some are in favour of civil and political rights as these are more viable in realising a healthy and clean environment as rightly stated "international courts and tribunals are likely to be more easily persuaded that civil and political rights are capable of creating practical and enforceable obligations in relation to environment and related matters", 41 .

However, some have argued for the use of second generation rights that economic, social, and cultural rights, over first generation rights in the protection of the environment because of the fact that many of these rights have a direct bearing upon environmental conditions. However, it has been observed that this will not be an easy task for a full realisation and useful impact of these rights ${ }^{42}$.

\footnotetext{
${ }^{39}$ Report by the Special Rapporteur on environment and Development, E/CN.4/sub.2/1994/9 96July 1994).

${ }^{40}$ Daniel Moecckli et al op. cit. p. 627.

${ }^{41}$ Sands, Principles of International Environmental Law, (Manchester University Press 2001) p. 297.

${ }^{42}$ Ibid. For further view see also Anderson, 'Human Rights Approaches to Environmental Protection: An Overview' in Boyle and Anderson, Human Rights Approaches to Environmental Protection (Oxford University Press 1996) p. 6.
} 


\section{European Convention on Human Rights}

There is no provision under the European Convention on Human Rights (ECHR) with regard to substantive environmental human right so cases on environmental degradation were regarded as inadmissible by the European Court of Human Rights ${ }^{43}$.

In the Hatton $v$ UK case, the European Court adopted a very restricted and deferential view towards the State's position regarding environmental human rights and the possibility of redressing environmental degradation.

In Fadeya $v$ Russia ${ }^{44}$ the European Court noted the breach of national laws by the defendant state but also clarified that not every instance of environmental degradation will constitute a breach of Article 8 ECHR.

There would be no claim under Article 8 if the harm complained of was negligible in comparison to the environmental hazards inherent to life in modern city. The Court held that the emissions from the industrial plant had affected the applicant's health, making her more vulnerable to various diseases as well as affecting the enjoyment of her home ${ }^{45}$.

The decisions in the cases mentioned above and the reasoning put forward by the courts clearly show that the European Court of Human Rights is willing to remedy environmental degradation through human rights despite the lack of specific environmental right in the ECHR ${ }^{46}$. This is because in Kyrtatus $v$ Greece $^{47}$ the Court said no provision of the European Convention is designed to protect the environment itself, unless the rights of individuals are directly affected. So it could be said that the right to health of the people is invariably connected to the right to the protection of the environment against degradation whatever the source might be.

\section{Other International Treaties}

The Other treaties which have to do with indirect substantive environmental rights include the International Labour Organisation (ILO) Convention NO. 169 and this relates to Indigenous and Tribal Peoples in Independent Countries most importantly Article 14, regarding ownership and possession of land, and Article 15, regarding the right to participate in the use, management, and conservation of natural resources. As rightly stated,

\footnotetext{
${ }^{43}$ For further reading and analysis of cases brought before court in relation to Article 8, Article 2-right to life with reference to healthy and clean environment see the following cases: Powell and Raynor v UK (1996) 12 EHRR 385; On Environmental Pollution see Lopez Ostra v Spain (1996) 20 EHRR 27; Hatton v UK (2002) 34 EHRR 1.

44 (2007) 45 EHRR 10.

${ }^{45}$ Case as reported by Daniel Moecklei et al, op. cit. 631.

${ }^{46}$ Ibid.

${ }^{47}$ (2005) 20 EHRR 16.
} 
"these indirect environmental human rights should be viewed from the perspective of the culture and religion of indigenous peoples for whom the link with land and the environment and natural resources is frequently part and parcel of their identity as human beings" ${ }^{, 48}$. Furthermore, it is also established that 'they are also linked to the question of self-determination. Therefore, environmental rights are at the heart of protections for indigenous ${ }^{49}$ population'.

\section{Sources of Environmental Degradation and their effects on human health}

The environment is made up of conditions, circumstances among so many other things affecting people's lives. Physical, chemical and biotic factors combine to cause environmental degradation. Environmental degradation can lead to scarcity of resources such as water and land.

Human activities due to over population along with so many other factors can affect the environment either in a positive or negative way. For instance the use of pesticides for agriculture pollutes the atmosphere or it could find its way into the drainage system and sewers. Thermal power stations, burning of fossil fuels, exhaust fumes emitting harmful pollutants such as sulphur dioxide, carbon monoxide, among so many others causing acid rain, global warming, and the malfunctioning of human haemoglobin come from economic and domestic activities ${ }^{50}$.

There are many sources of environmental degradations. We shall endeavour to discuss the major environmental factors and the health problems they cause to human kind in the sections following.

Available information as per UN estimation, suggests that more than two million deaths and billions of illnesses a year are traceable to water pollution and as a consequence of these water becomes scarce hence health problems become compounded ${ }^{51}$.

\section{Air Pollution}

"As per the estimation of UN, urban air pollution is responsible for 300,000-700,000 deaths annually and creates chronic health problems for many more peoples. Restrictions on vehicles and industrial

\footnotetext{
${ }^{48}$ Daniel Moecklei et al op. cit. p. 632.

${ }^{49}$ Ibid.

${ }^{50}$ Uchendu, S. N. Environmental Management and Protection, (Enugu Precision Printers and Publishers 2002)

51 Young, Gordon J. Et al Global Water Resource Issues, (Cambridge University Press 2004); Raleigh et al, 'Climate Change, Environmental Degradation, and Armed Conflict;, Volume 26, NO. (2007) Political Geography 674-694.
} 
activity during critical periods affect productivity, as does the effect of acid rain on forests and water bodies" ${ }^{, 52}$.

Air pollution is the contamination of the air with unwanted gas, smokes, particles and other substances. It is also regarded as waste remaining from the ways we produce goods and generates energy to heat our environment. According to the World Bank Report

"air pollution is the presence in the outdoor atmosphere of one or more contaminants such as dust, fumes. Gas, mists, odour, smoke or vapour in such quantities, characteristics and duration as to make them actually harmful or potentially injurious to human, plant or animal, life or property, or which unreasonably interfere with the comfortable enjoyment of life and property, ${ }^{, 53}$.

\section{Solid and Hazardous Wastes}

Diseases are spread by uncollected garbage and blocked drains. The health risks from hazardous wastes are typically more localised, but often acute wastes affect productivity through the pollution of ground water resources $^{54}$.

\section{Soil Degradation}

Depleted soils can lead to risks of malnutrition for farmers. This leads to productivity losses due to siltation of reservoirs, transportation channels and other hydrologic investments. This directly affects the health of people. Malnutrition can lead to premature death ${ }^{55}$.

\section{Loss of Biodiversity}

Deforestation, death and disease can result from the localised flooding caused by deforestation. The extinction of plant and animal species will potentially affect the development of new drugs thereby impacting on the health of the people negatively. Loss of biodiversity also reduces the ecosystem adaptability consequently leading to the loss of genetic resources $^{56}$.

\footnotetext{
52 https://saferenvironment.wordpress.com/2008/08/18/effects-of-environment-degradation. Last accessed 02/01/2016.

${ }^{53}$ World Bank Water Supply and Wastes Disposal, Poverty and Basic Needs Series, September 1980

${ }^{54}$ Ibid.

55 Ibid.

${ }^{56}$ Ibid.
} 


\section{Climatic Change}

It has been estimated that Ozone depletion is responsible for perhaps 300,000 additional cases of skin cancer a year and 1.7 million cases of cataracts. Global warming may lead to increase in the risk of climatic natural disasters. As a result of global warming this has effect on sea-rise damage to coastal investments, regional changes in agricultural productivity as well as disruption of marine food chain ${ }^{57}$.

\section{Right to health under international law}

There have been many developments in international law with regard to the normative definition of the right to health. It could be viewed as both heath care and healthy conditions. Hence health is viewed from the perspective of rights; the paradigm invariably links health with laws, policies and practices which have to do with a functional democracy and the question of accountability. The right to health has evolved with rapid development under international law. Under international law, there is a right to health as a broader concept and it also extends to health care. Generally speaking, rights are inherently embedded within the social sphere and therefore determinants of health and ill health are not purely biological or 'natural' but also are consequences of societal relations ${ }^{58}$.

It has been established that "a rights perspective is entirely compatible with work in epidemiology that has established social determinants as fundamental causes of disease" ${ }^{\text {59 }}$.

The notion of a right to health was for the first time found in international law in the 1948 Universal Declaration of Human Rights (hereinafter called Declaration). This was unanimously adopted and proclaimed by the UN General Assembly as a common standard for humanity ${ }^{60}$.

\footnotetext{
${ }^{57}$ Ibid.

${ }^{58}$ UN Committee on Economic, Social and Cultural Rights. General Comment 14: The Right to the Highest Attainable Standard of Health. Geneva Switzerland: United Nations: 2000. UN Document E/C. 12/2000/4. Available at https//www.unhcr.ch/tbs/doc.nsf (symbol) /E,C.12.2000.4.En>.Open Document. Accessed April 26, 2005; See also Yamin AE.' Transformative Combination: Women's health and human rights,' Volume 52 (1997) Journal of American Women's Association pp. 169-173.

${ }^{59}$ Alicia Ely Yamin, 'The Right to Health Under International Law and Its Relevance to the United States’, Volume 95 NO. 7 American Journal of Public Health July (2005) pp11561161; See also Link B. G., Phelan J, 'Social Conditions as fundamental Causes of Disease', (1995) Journal of Health and Social Behaviour', pp80-94; Mark S, 'The new Partnership of health and human rights: Human Rights Dialogue', 2001: 2:21-22. Available at https//www.cceja.org/viewMedia.php/PrmTemplate ID/8/PrmID/650 Accessed March 13, 2005.

${ }^{60}$ Universal Declaration of Human Rights United Nations General Assembly Resolution 217 A (111). New York, NY: United Nations, 1948.
} 
Article 25 of the Declaration provides for the right to health to a "standard of living adequate for the health and well-being of himself and his family, including.....medical care and.....the right to security in the event of.....sickness, disability....or other lack of livelihood in circumstances beyond his control', As to what constitutes the components of a right to health has not been defined by the Declaration but this provision invariably includes and goes beyond medical care.

However, provisions in laws and policies differ from one country to another. The highest attainable standard as provided by the Declaration cannot be the same in all countries of the world. Therefore, "the right to health demands, as do all human rights international assistance and cooperation, 61 .

The expression to a "highest attainable standard" of health is taken from the World Health Organisation Constitution ${ }^{62}$ presupposes a reasonable standard $^{63}$. This means that the state has a role to play in seeing to it that it provides for level playing ground socially with respect to health even though there remain factors which are clearly beyond the states ${ }^{64}$. Furthermore, the highest attainable standard will necessarily evolve overtime, in response to medical inventions, as well as demographic, epidemiological, and economic shifts ${ }^{, 65}$.

Apart from the ICESCR, there are other international and regional treaties that also recognise health as a right issue and there is consensus on this ${ }^{66}$. Based upon a review of the international instruments as well as the interpretive documents it is clear that the right to health as it is when enshrined in international law encompasses not only health care but also

${ }^{61}$ UN Committee on Economic, Social and Cultural Rights, General Comment 14: The Right to the Highest Attainable Standard of Health Geneva Switzerland: United Nations: 2000. UN Document E/C/2/2004 14; Article 2 International Covenant on Economic, Social and Cultural Rights, New York, NY: United Nations, 1966 UN Document A/6316 Available at http://www.unhcr.ch/html/menu3/b/9ceser.htm. Accessed April26, 2005.

${ }^{62}$ World Health Organisation Constitution. Geneva, Switzerland 1946.

${ }^{63}$ Kinney E, 'The international right to health: What does this mean for our world', Volume 34 (2001) Indiana Law Review, pp1457-1475; Chapman A, 'Core obligations related to the right to health', in Chapman A. Russell S, (eds), Core Obligations: Building a Framework for Economic, Social and Cultural Rights 9New York: NY : Intersentia 2002 pp, 85-216.

${ }^{64}$ Toebes B, The Right to Health as a Right in International Law, (Oxford England: Intersentia/Hart 1999).

${ }^{65}$ Alicia Ely Yamin, op. cit. p.2 .

${ }^{66}$ International Convention on the Elimination of All Forms of Racial Discrimination, New York, NY: United Nations, 1996. UN Document A/6014. Available at http://www.unhchr.ch/html/menu3/6/d-icerd.htm. Accessed April 26, 2005. 
basic preconditions for health, such as potable water and adequate sanitation and nutrition ${ }^{67}$.

\section{States' Obligations}

Under International law, states that are party to a variety of different treaties assume tripartite obligations: (1) to respect the right to health by refraining from direct violations, such as systematic discrimination within the health system, (2) to protect the right from interference by third parties, through such measures as environmental regulation of third parties, and (3) to fulfil the right by adopting deliberate measures aimed at achieving universal access, as well as to preconditions for health ${ }^{68}$.

\section{Conclusion}

This article has established that a degraded environment arising from factors such as water pollution, air pollution, climate change as a consequence of global warming because of greenhouse gases among so many other factors constitute grave human health. These could lead to premature deaths and hence increase in morbidity. We have also seen that international law has developed rapidly in recent years with regard to the normative definition of the right to health. This amongst many other things includes both health care and healthy conditions. It therefore means the environment should be clean and healthy. A healthy environment is fundamental in the protection of the health of the people. Thus there is a link between the environment and how well it is managed and the health and right to health of humankind. The environment affects the lives of humans in so many ways including health of the people.

The international norms relating to the right to health have made standard provisions for evaluating states' obligations and also their degree of accountability. It is therefore necessary that governments, international organisations and communities should and must work together at all levels to combat the health risks to human kind associated with environmental degradation and its contributing factors, such as climate change. Governments must endeavour to ensure that activities of companies, organisations and individuals must be in conformity with environmental

\footnotetext{
${ }^{67}$ Ibid; Convention Concerning Indigenous and Tribal peoples in Independent Countries (Convention 169), Geneva Switzerland: International Labour Organisation, 1989.

${ }^{68}$ UN Committee on Economic, Social and Cultural Rights General Comment 14: The Right to the Highest Attainable Standard of Health. Geneva, Switzerland United Nations: 2000 UN Document E/C. 12/2000/4, Kinney E, 'The International right to Health: What does this mean for our nation and our World'? Volume 34, (2001) Indiana Law Review pp. 14571475.
} 
protection towards healthy environment. If this is done human health will be protected.

\section{Recommendation}

Pollution of the biosphere and the control of air pollution emission can be achieved by the following methods: gravity, surface sink/tree planting, precipitation, reduction in degradation, use of smokeless fuels, air pollution reduction by exhaust, use of treatment plants to purify water, incineration $^{69}$.

There is the need to put in place enforceable right for the protection of the environment both internationally and nationally. In this way there will be respect to a clean environment by the application of legislation as this will ensure enforcement and protection of the right to health.

\section{References:}

Alicia Ely Yamin, 'The Right to Health Under International Law and Its Relevance to the United States', Volume 95 NO. 7 American Journal of Public Health July (2005)

Anderson, 'Human Rights Approaches to Environmental Protection: An Overview' in Boyle and Anderson, Human Rights Approaches to Environmental Protection (Oxford University Press 1996).

Boyle, 'Human Rights or Environmental Rights? A Reassessment' Volume 18 (2007) Fordham Environmental Law Report 471, 476

Malgosia FitzMaurice, 'Environmental Degradation', in Daniel Moeckli, Sangeeta Shah, and Sadesh Sivakumaran (eds) and David Harris (Consultant editor), International Human Rights Law (Oxford: Oxford University Press 2010)

Mohammed A, Alamin, ‘An Assessment of Nigeria's preparedness to Environmental Disasters From Its Commitment to International Environmental Treaties'; European Scientific Journal Volume 9 No. 32 November 2013 edition

Sajini Faith Iwejingi, 'Population Growth, Environmental Degradation and Human Health in Nigeria', Pakistan Journal of Social Sciences, Volume 8 No. 4 (2011)

Sands, Principles of International Environmental Law, (Manchester University Press 2001)

Uchendu, S. N. Environmental Management and Protection, (Enugu Precision Printers and Publishers 2002)

Young, Gordon J. Et al Global Water Resource Issues, (Cambridge University Press 2004); Raleigh et al, 'Climate Change, Environmental

\footnotetext{
${ }^{69}$ Angela K, op. cit. p.12.
} 
Degradation, and Armed Conflict;, Volume 26, NO. (2007) Political Geography

Angela Kesiena Etuonovbe, 'The Devastating Effects of Environmental Degradation- A Case Study of the Niger delta Region of Nigeria', TSIDEnvironment and Land Use Planning FIG Working Week 2009 Surveyors Key Role in Accelerated Development Eitat, Israell, 3-8 May, 2008.

Chertow, Marian. R, 'The IPAT equation and its variants', Volume 4 no. 4 (2001) Journal of Induetrial Ecology, pp. 13-28; Huesemann, M.H. and Joyce A, Huesmann, 'Technofix: Why Technology Won't Save US or the Environment', Chapter 6, Sustainability or Collapse? (New Society Publishers 2011) Available at (http://www.newtechnology and society, org), Kravchencko and Bonine, Human Rights and the Environment: Cash, Law and Policy, (Carolina Academic Press 2008) The Oxford Advanced Learner's Dictionary International Student's Edition, (Oxford: Oxford University Press 2015). 